\title{
Effect of natural active compound addition on mechanical and functional properties of canna starch based edible film
}

\author{
Budi SANTOSO ${ }^{1 \star}$ (D), Tripena Las Dame SINAGA ${ }^{1}$, Gatot PRIYANTOํ․ HERMANTO ${ }^{1}$
}

\begin{abstract}
This research objective was to determine the additional effect of biopolymer materials of red palm oil and miserly leave extract on mechanical and functional characteristics of canna starch based edible film. The method used in this research was factorial randomized block design with two treatment factors consisting of red palm oil $(0.5 ; 1.0$; and $1.5 \% \mathrm{v} / \mathrm{v})$ and miserly leave extract $(1.0 ; 2.0 ;$ and $3.0 \% \mathrm{v} / \mathrm{v})$. Research results showed that edible film had thickness of 0.18 to $0.24 \mathrm{~mm}$, elongation percentage of 16.7 to $19.00 \%$, compressive strength of 33.87 to 48.40 gf, water vapour transmission rate of 11.97 to $44.32 \mathrm{~g}^{-2} \mathrm{~m}^{-2} . \mathrm{d}^{-1}$, total phenol of 389.31 to $488.45 \mathrm{ppm}$, antioxidant activity of 389.31 to $488.45 \mathrm{ppm}$ and inhibition zone diameters of 0.1 to $0.73 \mathrm{~mm}$, respectively. The concentration increase of red palm oil had increased the thickness, compressive strength, total phenol, antioxidant and antibacterial activity of the edible film, but the percent elongation and the rate of water vapor transmission had decreased. Water vapor transmission rate, compressive strength, total phenol, antioxidant and antibacterial activity had increased with the increase in miserly leave extract concentration. The best edible film formula was red palm oil with a concentration of $1.5 \%(\mathrm{v} / \mathrm{v})$ and $1 \%(\mathrm{v} / \mathrm{v})$ miserly leave extract $\left(\mathrm{A}_{3} \mathrm{~B}_{1}\right)$.
\end{abstract}

Keywords: antibacterial; antioxidant; miserly; red palm oil; mechanical property.

Practical Application: The role of red palm oil and miserly leave extract are synergistic and antagonistic in the formation of functional edible film.

\section{Introduction}

Edible film is food packaging material which is safe to be consumed by human and has high potential to be developed in order to protect food from deterioration, maintaining quality and extending shelf life. It has unique advantage because it can be used for new product development of functional compound such as food additive, flavor, antibacterial and antioxidant compounds.

Research on edilble film, especially starch based edible film continues to be developed. Starch resources used in this development are consisted of canna tubers, cassava tubers, ceeping edible tubers and arrowroot tubers. Santoso (2011) had stated that edible film from canna tuber starch had better physicochemical characteritics than that of cassava tubers and gadung bulbs. Along with the progress of research, edible film that has good mechanical properties such as thickness, elongation percentage and water vapour transmission rate are considered insufficient. Therefore, development of functional edible film that has antibacterial and antioxidant properties is required.

Addition of functional compounds from natural resource had positive and negative effects on mechanical properties of edible film. Zheng et al. (2018) had reported that the addition of hardleaf oatchestnut starch and Litsea cubeba oil on chitosan based edible films could significantly increase antimicrobial activity, tensile strength from 27.33 to $33.54 \mathrm{MPa}$, and antioxidant activity of $31.67 \%$. Lee et al. (2019) explained that active composite edible film based on hydroxypropyl methylcellulose which is incorporated with oregano essential oil nanoemulsions could increase antioxidant properties by $46 \%$ and antibacterial by high inhibition zone of $47.5 \mathrm{~mm}$. The addition impact of biopolymer materials containing functional compound on the decrease of mechanical property of edible film should be minimized because edible film will have optimal function if its mechanical property and functional property are equally good. Therefore, the choice of functional biopolymer materials to achieve this objective is very important. One of functional biopolymer materials that can be used for edible film are red palm oil and miserly leaves extract. Santoso et al. (2020) revealed that canna starch-based edible film incorporated with red palm oil $(1 \% \mathrm{v} / \mathrm{v})$ and gambier extract filtrate $(20 \% \mathrm{v} / \mathrm{v})$ had produced antioxidant and antibacterial edible films with $\mathrm{IC}_{50}$ values and inhibition diameter of $12.40 \mathrm{ppm}$ and $5 \mathrm{~mm}$, respectively whereas the mechanical properties of the edible film was not effected significantly. Mechanical property of edible film was effected not only by biopolymer material type but also by the form of biopolymer material such as total solid concentration that had effect on decrease of elongation percentage and increase of edible film thickness (Santoso et al., 2019b). Based on this consideration, miserly leave is used in form of extract

Phoon et al. (2018) had explained that red palm oil (RPO) contains carotenoids (500-700 ppm), tocopherols and tocotrienols (500-1000 ppm) and the main carotenoids contained in RPO are $\alpha$ - and $\beta$-carotene, which act as provitamin A (Lee et al., 2018). Purnama et al. (2020) had reported that RPO has low content of saturated fats as a result of fractionation. RPO can be applied to 
food products such as cooking oil, shortening, spreads, cooking oil, salad dressings, and margarine. Miserly leave contains active compounds of phenolic, flavonoid, flavon and flavanon, polyphenol, saponin, tanin, alkaloid and essential oil (Sahid \& Murbawani, 2017). Cheng et al. (2015) and Lutpiatina et al. (2017) showed that miserly leave extract had antioxidant characteristic $\left(\mathrm{IC}_{50} 5.92 \mathrm{mg} / \mathrm{mL}\right.$ ).

The research objective was to determine the effect of biopolymer materials addition consisting of red palm oil and miserly leave extract on mechanical and functional characteritics of canna starch based edible film.

\section{Reseach method}

\subsection{Materials and equipments}

Materials used in this research are consisted of: 1) Miserly leaves (Cosmos caudatus) obtained from Indralaya market; 2) Red palm oil of "Salmira" brand; 3) Canna starch of "Mama Kamu" brand containing amylose and amylopectin levels of 21.14 to $24.44 \%$ and 75.56 to $78.86 \%$, respectively; 4) Bacterial culture of Staphylococcus aureus FNCC 0047 from Chemical Laboratory of Agricultural Product, Sriwijaya University; 5) Glycerol; 6) Carboxymethyl Cellulose (CMC) and 7) Nutrient agar (NA). Equipments are consisted of: 1) Hot plate of Torrey Pines Scientific brand; 2) Vacuum pump (model; DOA-P504-BN); 3) Magnetic stirrer; 4) Vortex; 5) Oven; 6) Incubator; 7) Dessicator; 8) Haze meter seri NDH - 200, Nipon Denshoku Kogyo Co Ltd; 9) Micrometer (Roch) (A281500504, Sisaku SHO Ltd, Japan); 10) Testing Machine. MPY (Type: PA-104-30, Ltd Tokyo, Japan); 11) spectrophotometer; and 12) Water vapor transmission rate tester Bergerlahr.

\subsection{Design of experiment}

Treatment factors in this study are consisted of red palm oil (A): $A_{1}=0.5 ; A_{2}=1.0$; and $A_{3}=1.5(\% \mathrm{v} / \mathrm{v})$ as well as miserly leave extract $(\mathrm{B})$ : $\mathrm{B}_{1}=1.0 ; \mathrm{B}_{2}=2.0$; and $\mathrm{B}_{3}=3.0(\% \mathrm{v} / \mathrm{v})$. Research was done by using factorial randomized block design with three replications for each treatment. Data from research results were processed with ANOVA by using SAS program of window 9 version. The observed parameters were consisted of thickness, compressive strength, elongation percentage, and water vapour transmission (American Society for Testing and Materials, 1997). The equipment used for testing of thickness, elongation percent, compressive strength and water vapor transmission rate of edible film were micrometer (Roch) (A281500504, Sisaku SHO Ltd, Tokyo, Japan), testing machine MPY (Type: PA-104-30, Ltd Tokyo, Japan), the Brookfield CT3 texture analyzer, and water vapor transmission rate tester of Bergerlah cup method, respectively. Total phenol content is determined by using the Folin-Ciocalteu Method (Orak, 2006), antioxidant activity was tested using the DPPH (2,2 dipenyl-1-picrylhidrazyl) method (Maesaroh et al., 2018) and testing for antibacterial activity is by using the well diffusion method with the test bacteria of Staphylococcus aureus FNCC 0047 (Misna \& Diana, 2016).

\subsection{Production of miserly leave extract}

Production of miserly leave extract was carried out using protocol of Lutpiatina et al. (2017). Miserly leave is washed and dried using drying oven for 6 hours at temperature of $50{ }^{\circ} \mathrm{C}$. Dry miserly leave is mashed by using blender. Miserly leave powder is weighed as much as $25 \mathrm{~g}$ and put into $200 \mathrm{~mL}$ water at temperature $40 \pm 2{ }^{\circ} \mathrm{C}$. The mixture is stirred by using magnetic strirer for 10 minutes and then left over for 1 hours, followed by sieving with filter paper in orde to take its extract. Filtrate is evaporated for 1 hour at temperature of $100{ }^{\circ} \mathrm{C}$; and finally, filtrate of miserly leave extract is obtained.

\subsection{Production of edible film}

Production of edible film was carried out using protocol of Santoso (2011). Canna starch as much as $6 \%(\mathrm{w} / \mathrm{v})$ is put into Beaker glass and water is added up to mark of $100 \mathrm{~mL}$. Strach suspension is stirred by using magnetic stirrer while being heated by using hotplate at temperature of $65^{\circ} \mathrm{C}$ for 15 minutes until perfect gelatinization is obtained. Gelatinized starch suspension is added with glycerol $1 \%(\mathrm{v} / \mathrm{v})$ in which stirring process and heating at temperature of $65^{\circ} \mathrm{C}$ is maintained until formation of homogenous suspension. Suspension is added with miserly leave extract according to treatments $(1 ; 2 ;$ and $3 \% \mathrm{v} / \mathrm{v})$ and stirred until homogenous in which temperature of $65^{\circ} \mathrm{C}$ is maintained and subsequently added with CMC as much as $1 \%(\mathrm{w} / \mathrm{v})$. Suspension is added with red palm oil according to treatments $(0.5 ; 1.0$; and $1.5 \% \mathrm{v} / \mathrm{v}$ ) and then the suspension is homogenized for 3 minutes with a rotation of $11000 \mathrm{rpm}$. Suspension as much as $15 \mathrm{~mL}$ is poured into petri dish having diameter of $9 \mathrm{~cm}$ and dried within oven for 12 hours at temperature of $70^{\circ} \mathrm{C}$. After drying operation, edible film is released from petri dish and wrapped in plastic and then put into a desiccator.

\section{Results and discussion}

\subsection{Thickness}

Thickness is one of mechanical property quality parameters for edible film besides elongation percetange, compressive strength and water vapour transmission rate. Japan International Standard (JIS) requires that maximum thickness for edible film is $0.25 \mathrm{~mm}$ (Japanese Industrial Standards, 1975). The edible film thickness produced in this research with magnitude in the range of 0.18 to $0.24 \mathrm{~mm}$ had fulfilled this standard.

Treatment of red palm oil had statistically significant effect on edible film thickness, whereas miserly leave extract treatment and interaction of both treatments had no significant effect on edible film thickness. Test of honestly significant different (HSD) (Table 1) showed that the higher the red palm oil concentration, the thicker the edible film produced. This can be explained through mechanicsm reaction of formation process of edible film matrix.

Reaction mechanism of edible film formation can be explained from biopolymer materials used in this study, in which canna starch, glycerol, miserly leave extract are all have hydrophylic characteristics, CMC has function as emulsifier and red palm oil has hydrophobic characteristics. The complex bond formed in edible film matrix is canna starch-glycerol-miserly leave extract-CMC-red palm oil. Red palm oil could distribute and insert between the complex chains, lowering the compactness of film network so that it has an effect on increasing the volume, 
which in turn affects the thickness of the edible film. The result was in agreement with result that was reported by Nilsuwan et al. (2016) in which the thickness of film incorporated with $75 \%$ palm oil was higher than that of film containing $50 \%$ palm oil when the same glycerol level was used $(p<0.05)$. Liaotrakoon \& Raviyan (2018) reveals that the thickness significantly increased $(p<0.05)$ from $0.14 \mathrm{~mm}$ for the whey protein isolate film with $6 \%$ palm oil and $40 \%$ glycerol to $0.18 \mathrm{~mm}$ for the film with $8 \%$ palm oil and $60 \%$ glycerol. Shabrina et al. (2017) explained that palmitat acid within red palm oil contains total solids which affect increase in thickness of edible film.

\subsection{Elongation percentage}

Elongation percentage of edible film produced in this research was in the range of 16.7 to 19.00 percent. This result is much lower than those reported by Santoso et al. (2019b, 2020) successively with magnitude of 58.67 to 126.67 percent by using biopolymer materials formulation of canna starch-glycerol-gambier powder filtrate-CMC-red palm oil as well as with magnitude of 32.14 to 50.30 percent with edible film formulation of corn starch-HPMC-glycerol-gambier powder filtrate-tween 80-red palm oil. It can be concluded from those studies that elongation percentage of edible film is not only determined by starch type, but also by the ratio of biopolymer materials that have hydrophilic and hydrophobic characteritics in edible film formulation. The higher the concentration of hydrophobic components, the lower the percentage of elongation of the edible film and the opposite was true. In addition, the elongation percentage of edible film produced in this research had not yet fulfilled the JIS 1975 Standard with minimum threshold level of 70 percent.

The elongation percentage of edible film is significantly affected by red palm oil treatment, whereas miserly leave extract treatments as well as treatment interaction of red palm oil and miserly leave extract had no significant effect. The results of HSD 5\% test (Table 1) showed that the higher the red palm oil concentration, the elongation percentage of edible film tend to be lower. It is known that red palm oil has non-polar characteristic or hydrophobic which have effect on decreasing of edible film elasticity. This is in line with statement by Krochta et al. (1994) that formation components of edible film are consisted of three basic ingredients namely hydrocolloid, lipid and composite. Lipid is biopolymer material having non-polar characteristic and very rarely used singly in edible film making because it is very stiff and capable to decrease edible film elasticity.

\subsection{Compressive strength}

Compressive strength describes the maximum compressive force that can be retained by edible film. The magnitude of average compressive strength was in the range 33.87 to 48.40 gf whereas the highest and the lowest values were found on $A_{3} B_{3}$ and $A_{1} B_{1}$ treatments, respectively. The average value of the compressive strength of the edible film is shown in Figure 1.

Analysis of variance showed that the treatment of red palm oil, miserly leave extract, and the interaction of the two treatments had significant effect on the compressive strength of the edible film. The compressive strength of the edible film increased with increasing concentration of red palm oil (Table 1). Red palm oil contains unsaturated fatty acids which are liquid at room temperature so that they have high mobility to spread evenly in the composite edible film matrix. This resulted in a compact film matrix which had an impact on increasing the compressive strength of the edible film. Santoso et al. (2018) explained that a homogeneous film suspension had produced solid edible film so that it affects the mechanical properties of the edible film. The increase in the compressive strength of the edible film occurred after the miserly leave extract was added (Table 2). It is explained that miserly leave extract had effect on the addition of total solids in the edible film matrix. The higher the total solids concentration, the higher the compressive strength of the edible film. Santoso et al. (2019a) reported that the compressive strength of canna starch-based edible films incorporated with protein extract was 51.09-68.87 gf.

Table 1. Honestly significant different (HSD) ( $\alpha=5 \%$ ) test for treatment effect of red palm oil on thickness, elongation percentage, compressive strength, and water vapour transmission rate.

\begin{tabular}{ccccc}
\hline Treatment $(\% \mathrm{v} / \mathrm{v})$ & Thickness $(\mathrm{mm})$ & Elongation percentage (\%) & Compressive strength (gf) & $\begin{array}{c}\text { Water vapour transmission } \\
\text { rate }\left(\mathrm{g} \cdot \mathrm{m}^{-2} . \mathrm{d}^{-1}\right)\end{array}$ \\
\hline $\mathrm{A}_{1}(0,5)$ & $0.18 \pm 0.006 \mathrm{a}$ & $18.78 \pm 0.19 \mathrm{a}$ & $36.59 \pm 2.84 \mathrm{a}$ & $34.657 \pm 8.46 \mathrm{a}$ \\
$\mathrm{A}_{2}(1,0)$ & $0.21 \pm 0.006 \mathrm{~b}$ & $17.67 \pm 0.34 \mathrm{~b}$ & $39.57 \pm 4.31 \mathrm{~b}$ & $21.774 \pm 4.73 \mathrm{~b}$ \\
$\mathrm{~A}_{3}(1,5)$ & $0.24 \pm 0.019 \mathrm{~b}$ & $16.89 \pm 0.38 \mathrm{c}$ & $44.24 \pm 4.46 \mathrm{c}$ & $15.193 \pm 3.06 \mathrm{c}$ \\
\hline
\end{tabular}

Remarks: Numbers followed by the same letter at the same column are not significantly different.

Table 2. Honestly significant different (HSD) ( $\alpha=5 \%$ ) test for treatment effect of miserly leave extract on compressive strength, water vapour transmission rate, total phenol, antioxidant and antibacterial activity.

\begin{tabular}{|c|c|c|c|c|c|}
\hline Treatment & $\begin{array}{l}\text { Compressive strength } \\
\text { (gf) }\end{array}$ & $\begin{array}{l}\text { Water vapour transmission } \\
\text { rate }\left(\mathrm{g} \cdot \mathrm{m}^{-2} \cdot \mathrm{d}^{-1}\right)\end{array}$ & Total phenol (mg. $\left.\mathrm{L}^{-1}\right)$ & $\begin{array}{l}\text { Antioxidant activity } \\
\left(\mathrm{IC}_{50}\right)\end{array}$ & $\begin{array}{l}\text { Antibacterial activity } \\
(\mathrm{mm})\end{array}$ \\
\hline B1 (1\%v/v) & $36.27 \pm 2.93 a$ & $18.973 \pm 8.60 \mathrm{a}$ & $196.94 \pm 85.85 a$ & $450.353 \pm 36.92 \mathrm{a}$ & $0.296 \pm 0.20 \mathrm{a}$ \\
\hline B2 $(2 \% v / v)$ & $40.16 \pm 4.28 b$ & $23.455 \pm 7.78 b$ & $222.5 \pm 102.51 b$ & $444.214 \pm 39.16 b$ & $0.359 \pm 0.18 b$ \\
\hline B3 $(3 \% \mathrm{v} / \mathrm{v})$ & $43.98 \pm 4.44 c$ & $29.195 \pm 13.58 c$ & $245 \pm 115.98 c$ & $424.881 \pm 38.20 \mathrm{c}$ & $0.415 \pm 0.29 c$ \\
\hline
\end{tabular}

Remarks: Numbers followed by the same letter at the same column are not significantly different. 


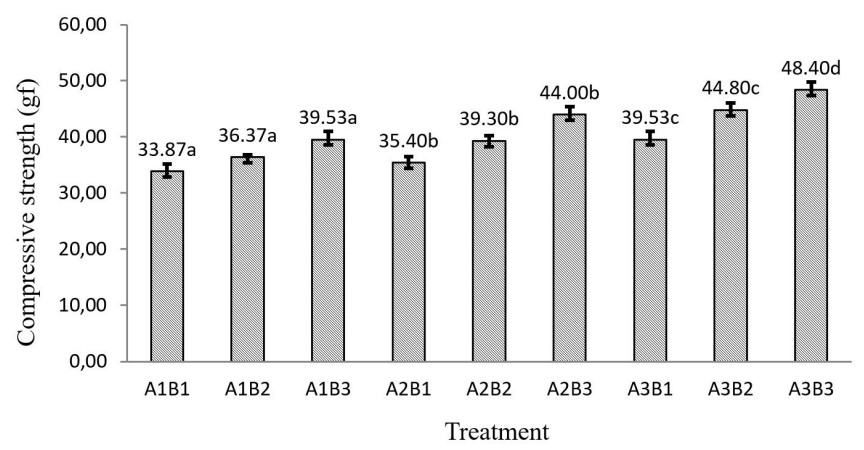

Figure 1. Average of compressive strength (gf) for canna starch based edible film added with natural active compounds.

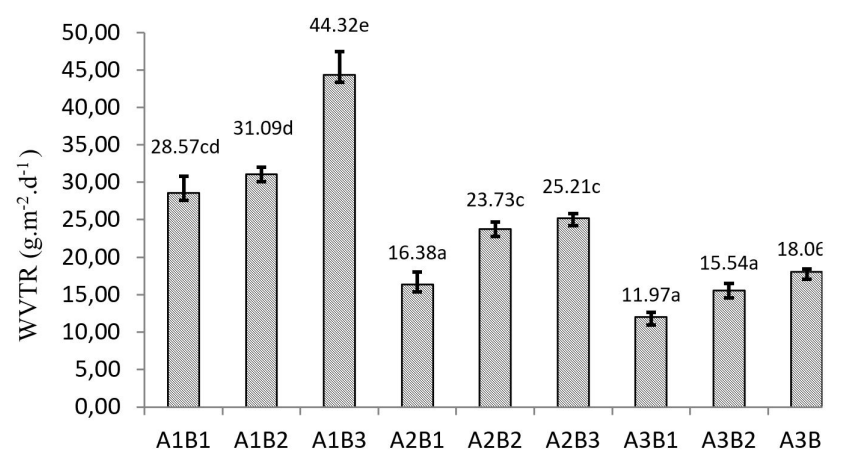

Treatment

Figure 2. Average of water vapour transmission rate (WVTR) for canna starch based edible film added with natural active compounds.

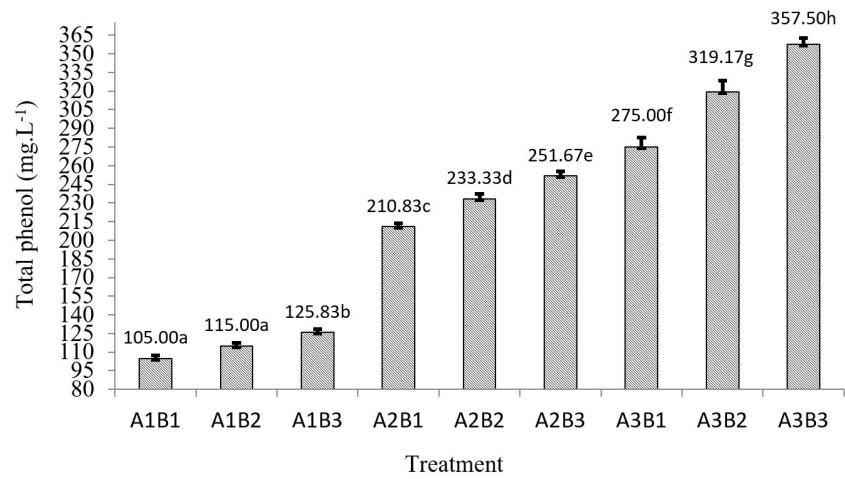

Figure 3. Average value of total phenol (mg. $\left.\mathrm{L}^{-1}\right)$ for canna starch based edible film added with natural active compounds.

\subsection{Water vapour transmission rate}

Water vapour transmission rate is very important quality parameter in edible film besides thickness and elongation percentage. JIS 1975 requires that water vapour transmission rate for edible film is at a minimum of $10 \mathrm{~g} \cdot \mathrm{m}^{-2} \mathrm{~d}^{-1}$. Most of edible film produced in this research had water vapour transmission rate of 11.97-44.32 g.m $\mathrm{m}^{-2} \cdot \mathrm{d}^{-1}$ which not fulfill JIS 1975 Standard. However, treatments of red palm oil with concentration of $1.5 \%$ $(\mathrm{v} / \mathrm{v})$ and miserly leave extract with concentration of $3 \%(\mathrm{v} / \mathrm{v})$ produced water vapour transmission rate of $11.97 \mathrm{~g} \cdot \mathrm{m}^{-2} \cdot \mathrm{d}^{-1}$ which is close to JIS 1975 Standard. Average value of water vapour transmission rate for edible fim is presented in Figure 2.
The treatments of red palm oil, miserly leave extract and interaction of both had significant effect on water vapour transmission rate. Water vapour transmission rate of edible film has decrease with the increasing of red palm oil concentration (Table 1). This is due to effect of non-polar characteristic from red palm oil. The existence of non-polar compound or hydrophobic compound in edible film matrix causing moisture permeability decrease toward edible film. Thakur et al. (2017) had stated that addition of several lipid acids such as palmitat acid, oleat acid and stearate acid into formulation of starch based edible film can decrease water vapour transmission rate.

Water vapour transmission rate of edible film is increasing with increasing of miserly leave extract concentration (Table 2). It is known that miserly leave extract has hydrophylic characteristic so that the higher the miserly leave extract concentration, the higher the hydrophilic component in edible film matrix so that edible film is easily penetrated by water vapour. Basiak et al. (2017a) had reported that edible film matrix with high hydrophilic component, in this case is amylose, had effect on increasing of water vapour transmission rate of edible film.

Interaction treatment of red palm oil and miserly leave extract (Figure 2) showed that red palm oil at higher concentration than miserly leave extract concentration tend to produce lower water vapour transmission rate of edible film. This can be explained by effect of ratio of hydrophobic and hydrophilic components within complex compound in edible film matrix. Complex compound that is formed within edible film matrix is canna starch-glycerol-miserly leave extract-CMC-red palm oil. It is previously mentioned that red palm oil is hydrophobic group, whereas miserly leave extract is hydrophilic group. Higher level of hydrophobic group than that of hydrophylic group results in lower water vapour transmission rate. Ratio increase of hydrophylic group (starch-protein) in edible film matrix had significant effect on increase of water vapour transmission rate, but edible film has more homogenous microstructure (Basiak et al., 2017b). Mahcene et al. (2020) had stated that addition of essential oil from medicinal plants into alginate edible film matrix not only capable to hamper pathogenic bacteria growth, but also to decrease water vapour transmission rate of edible film.

\subsection{Total phenol}

Edible film produced in this research had total phenol concentration in the range of 105 to $357.50 \mathrm{mg}$.L $\mathrm{L}^{-1}$. Average value of total phenol for each treatment combination is shown in Figure 3.

Analysis of variance results showed that treatments of red palm oil, miserly leave extract and their interaction had significant effect on total phenol concentration of edible film. Total phenol of edible film is higher with the increase of red palm oil concentration (Table 3). This is understandable because red palm oil is antioxidant sources. Atawodi et al. (2011) clarify that red palm oil not only contains antioxidant compounds such as carotenoid and vitamin E, but also contains phenolic compound mixture rich in antioxidants with IC50 value of $95 \mu \mathrm{M}$ and radical scavenging activities of $219 \mu \mathrm{M}$. 
Table 3. Honestly Significant Different ( $\alpha=5 \%$ ) test for treatment effect of red palm oil on total phenol, antioxidant activity, and antibacterial activity.

\begin{tabular}{cccc}
\hline $\begin{array}{c}\text { Treatment } \\
(\% \mathrm{v} / \mathrm{v})\end{array}$ & $\begin{array}{c}\text { Total phenol } \\
\left(\mathrm{mg} \cdot \mathrm{L}^{-1}\right)\end{array}$ & $\begin{array}{c}\text { Antioxidant } \\
\text { activity }\left(\mathrm{IC}_{50}\right)\end{array}$ & $\begin{array}{c}\text { Antibacterial } \\
\text { activity }(\mathrm{mm})\end{array}$ \\
\hline $\mathrm{A} 1(0,5)$ & $115.28 \pm 10.42 \mathrm{a}$ & $479.83 \pm 12.69 \mathrm{a}$ & $0.137 \pm 0.03 \mathrm{a}$ \\
$\mathrm{A} 2(1,0)$ & $231.95 \pm 20.46 \mathrm{~b}$ & $435.592 \pm 14.18 \mathrm{~b}$ & $0.422 \pm 0.22 \mathrm{~b}$ \\
$\mathrm{~A} 3(1,5)$ & $317.22 \pm 41.28 \mathrm{c}$ & $404.024 \pm 13.18 \mathrm{c}$ & $0.511 \pm 0.07 \mathrm{c}$ \\
\hline
\end{tabular}

Remarks: Numbers followed by the same letter at the same column are not significantly different.

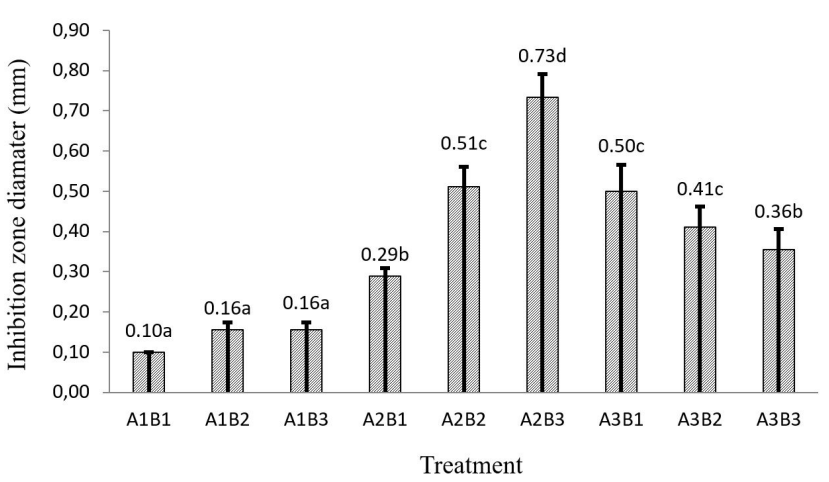

Figure 4. Average value of inhibition zone diameters $(\mathrm{mm})$ for canna starch based edible film added with natural active compounds.

The increase of miserly leave extract concentration results in increase of total phenol in edible film (Table 2). The study results by Mediani et al. (2014) showed that miserly leave contains antioxidant compound with $\mathrm{IC}_{50}$ value of $0.0223 \mathrm{mg} \cdot \mathrm{mL}^{-1}$ and total phenolic concentration of $27.4 \mathrm{GAE} / 100 \mathrm{~g}$ ). Figure 3 showed that interaction treatments of red palm oil and miserly leave extract have synergy in increasing total phenol of edible film, that is the higher concentration of both treatments result in higher total phenol of edible film.

\subsection{Antioxidant activity}

Antioxidant activity in edible film produced in this research was categorized as very weak with $\mathrm{IC}_{50}$ values in the range of 389.31 to $488.45 \mathrm{ppm}$. Treatments of red palm oil and miserly leave extract had significant effect, but their interaction had no significant effect. Higher concentration of red palm oil results in higher antioxidant activity of edible film (Table 3 ) and similar situation was occurred in miserly leave extract treatment (Table 2). It is previously mentioned that both of red palm oil and miserly leave extract had high antioxidant activity. However, their antioxidant activities were lower than that of research results conducted by Atawodi et al. (2011) and Mediani et al. (2014). This happened because the effect of complex bonds within edible film matrix and process temperature at edible film formation. As mentioned earlier, the complex bonds within edible film matrix causes active groups of functional compound available in red palm oil and miserly leave extract are mostly bounded in that complex bonds resulting in decrease of free active groups in edible film matrix. It is known that the higher the free active groups available in functional compound of a system, the higher its functional characteristics. In addition, the effect of edible film formation process, especially temperature above $60^{\circ} \mathrm{C}$, can cause oxidation of antioxidant compound.

\subsection{Antibacterial activity}

Edible film produced in this research had antibacterial activity with inhibition zone diameters in the range of 0.1 to $0.73 \mathrm{~mm}$. Average value of inhibition zone diameters of edible film is shown in Figure 4. Treatments of red palm oil and miserly leave extract and their interactions had significant effect on antibacterial activity of edible film.

Antibacterial activity of edible film is increasing along with increasing of red palm oil concentration (Table 3). According to Siregar et al. (2018), red palm oil contains 10 solid lipid acids consisting of laurat, miristat, palmitat, palmitoleat, stearat, oleat, linoleat, linolenat, arakidat and gadoleat. Ayustaningwamo (2010) had added that laurat acid concentration in red palm oil is $0.09 \%$. Laurat acid is the main medium chain on coconut oil that has efficacy as antivirus, antibacterial and antiprotozoal (Enig, 1999).

The increase of miserly leave extract concentration in edible film formulation is followed by the increase of antibacterial activity (Table 2). This is because flavonoids within miserly leave capable to interfere bacterial cell membranes so that it hampers enzyme activity which in turn interfere the growth of bacteria. Sahid \& Murbawani (2017) had reported that fresh miserly leave and miserly leave powder contain total flavonoids with magnitude of $143.00 \mathrm{mg} / 100 \mathrm{~g}$ and $1089.79 \mathrm{mg} / 100 \mathrm{~g}$, respectively. Interaction treatments of red palm oil with concentration of $1 \%(\mathrm{v} / \mathrm{v})$ and miserly leave extract with concentration of $3 \%(\mathrm{v} / \mathrm{v})$ had produced the highest antibacterial activity (Figure 4 ). This is affected by the complex bound in edible film matrix, especially equilibrium between hydrophilic and hudrophobic components. In this case hydrophilic component is more dominant in complex bounding of canna starch-glycerol-miserly leave extract-CMC-red palm oil so that the role of antibacterial compound within miserly leave extract is also more dominant.

\section{Conclusion}

Canna starch-based edible film incorporated with red palm oil and miserly leave extract had antioxidant and antibacterial characteristics as well as mechanical properties that were close to the JIS 1975 standard.

\section{Acknowledgements}

The research/publication of this article was funded by DIPA of Public Service Agency of Universitas Sriwijaya 2020. SP DIPA023.17.2.677515/2020, revision 01, on March 16, 2020. In accordance with the Rector's Decree Number: 0685/UN9/SK.BUK.KP/2020, On July 15, 2020"

\section{References}

American Society for Testing and Materials - ASTM. (1997). Annual book of ASTM standards. Philadelphia: ASTM.

Atawodi, S. E., Yusufu, L. M. D., Atawodi, J. C., Asuku, O., \& Yakubu, O. E. (2011). Phenolic compounds and antioxidant potential of 
Nigerian red palm oil (Elaeis guineensis). International Journal of Biology, 3(2), 153-159. http://dx.doi.org/10.5539/ijb.v3n2p153.

Ayustaningwamo, F. (2010). Kinetic of oxidation stability parameter in red palm oil (thesis). Bogor: Bogor Agricultural Institute.

Basiak, E., Lenart, A., \& Debeaufort, F. (2017a). Effect of starch type on the physico-chemical properties of edible films. International Journal of Biological Macromolecules, 98, 348-356. http://dx.doi. org/10.1016/j.ijbiomac.2017.01.122. PMid:28137462.

Basiak, E., Lenart, A., \& Debeaufort, F. (2017b). Effects of carbohydrate/ protein ratio on the microstructure and the barrier and sorption properties of wheat starch-whey protein blend edible films. Journal of the Science of Food and Agriculture, 97(3), 858-867. http://dx.doi. org/10.1002/jsfa.7807. PMid:27197704.

Cheng, S. H., Barakatun-Nisak, M. Y., Anthony, J., \& Ismail, A. (2015). Potential medicinal benefits of Cosmos caudatus: a scoping review. Journal of Research in Medical Sciences, 20(10), 1000-1006. http:// dx.doi.org/10.4103/1735-1995.172796. PMid:26929767.

Enig, M. E. (1999). Coconut: in support of good health in the 21st century. In APPC'S XXXVI session and 30th Anniversarry. Pohnpei: Federated States of Micronesia.

Japanese Industrial Standards - JIS. (1975). Japanese Industrial Standart 21707. Japan: Japanese Standards Association.

Krochta, J. M., Baldwin, E. A., \& Nisperos-Carriedo, M. O. (1994). Edible coatings and films to improve food quality (pp. 1-24). Lancester: Technomic Publishing Co. Inc.

Lee, J. Y., Garcia, C. V., Shin, G. H., \& Kim, J. T. (2019). Antibacterial and antioxidant properties of hydroxypropyl methylcellulose-based active composite films incorporating oregano essential oil nanoemulsions. Lebensmittel-Wissenschaft + Technologie, 106, 164-171. http://dx.doi. org/10.1016/j.lwt.2019.02.061.

Lee, W. J., Tan, C. P., Sulaiman, R., Smith, R. L. Jr., \& Chong, G. H. (2018). Microencapsulation of red palm oil as an oil-in-water emulsion with supercritical carbon dioxide solution-enhanced dispersion. Journal of Food Engineering, 222, 100-109. http://dx.doi. org/10.1016/j.jfoodeng.2017.11.011.

Liaotrakoon, V., \& Raviyan, P. (2018). Modifying the properties of whey protein isolate edible film by incorporating palm oil and glycerol. Songklanakarin Journal of Science and Technology, 40(1), 243-249.

Lutpiatina, L., Amaliah, N. R., \& Dwiyanti, R. D. (2017). Inhibition power of miserly leave Extract (Cosmos Caudatus Kunth.) on Staphylococcus Aureus. The Journal of Medical Laboratory, 5(2), 83-91. http://dx.doi.org/10.33992/m.v5i2.116.

Maesaroh, K., Kurnia, D., \& Al Anshori, J. (2018). Comparison of the antioxidant activity test methods of DPPH, FRAP and FIC against ascorbic acid, gallic acid and quercetin. Chimica et Natura Acta, 6(2), 93-100. http://dx.doi.org/10.24198/cna.v6.n2.19049.

Mahcene, Z., Khelil, A., Hasni, S., Akman, P. K., Bozkurt, F., Birech, K., Goudjil, M. B., \& Tornuk, F. (2020). Development and characterization of sodium alginate based active edible films incorporated with essential oils of some medicinal plants. International Journal of Biological Macromolecules, 145, 124-132. http://dx.doi.org/10.1016/j. ijbiomac.2019.12.093. PMid:31843601.

Mediani, A., Abas, F., Tan, C. P., \& Khatib, A. (2014). Effects of different drying methods and storage time on free radical scavenging activity and total phenolic content of Cosmos caudatus. Antioxidants, 3(2), 358-370. http://dx.doi.org/10.3390/antiox3020358. PMid:26784876.

Misna, M., \& Diana, K. (2016). Antibacterial activity extract of garlic (Allium cepa L.) skin against Staphylococcus aureus. Galenika Journal of Pharmacy, 2(2), 138-144.
Nilsuwan, K., Benjakul, S., \& Prodpran, T. (2016). Influence of palm oil and glycerol on properties of fish skin gelatin-base films. Journal of Food Science and Technology, 53(6), 2715-2724. http://dx.doi. org/10.1007/s13197-016-2243-7. PMid:27478227.

Orak, H. (2006). Total antioxidant activities, phenolics, anthocyanins, polyphenoloxidase activities in red grape varieties. Electronic Journal of Polish Agricultural University Food Science and Technology, 9, I17-I118.

Phoon, K. Y., Ng, H. S., Zakaria, R., Yim, H. S., \& Mokhtar, M. N. (2018). Enrichment of minor components from crude palm oil and palmpressed mesocarp fiber oil via sequential adsorption-desorption strategy. Industrial Crops and Products, 113, 187-195. http://dx.doi. org/10.1016/j.indcrop.2018.01.039.

Purnama, K. O., Setyaningsih, D., Hambali, E., \& Taniwiryono, D. (2020). Processing, characteristics, and potential application of red palm oil: a review. International Journal of Oil Palm, 3(2), 40-55. http://dx.doi.org/10.35876/ijop.v3i2.47.

Sahid, A. P. N., \& Murbawani, E. (2017). The Effect of miserly leave powder (Cosmos caudatus) on blood glucose content of diabetes mouse induced by Streptozotocin. Journal of Nutrition College, 5(2), 51-57. http://dx.doi.org/10.14710/jnc.v5i2.16359.

Santoso, B., Apriliana, S., Priyanto, P., Hermanto, \& Wijaya, A. (2020). Improvement of bioactive edible film property by using gambier powder filtrate and red palm oil. Agritech, 40(2), 161-168. http:// dx.doi.org/10.22146/agritech.40601.

Santoso, B., Pratama, F., Hamzah, B., \& Pambayun, R. (2019a). The effect of ell's protein extract on the characteristics edible film from crosslinked modified canna starch. International Food Research Journal, 26(1), 161-165.

Santoso, B., Hazirah, R., Priyanto, G., Hermanto, \& Sugito. (2019b). Utilization of Uncaria gambir Roxb filtrates in the formation of bioactive edible films based on corn starch. Food Science and Technology, 39(4), 837-842. http://dx.doi.org/10.1590/fst.06318.

Santoso, B., Amilita, D., Priyanto, G., Hermanto, H., \& Sugito, S. (2018). Pengembangan Edible Film Komposit Berbasis Pati Jagung dengan Penambahan Minyak Sawit dan Tween 20. Agritech, 38(2), 119-124. http://dx.doi.org/10.22146/agritech.30275.

Santoso, B. (2011). Integration of modified starch, surfactan, protein and catechin on edible film making (dissertation). Postgraduate School Program, Sriwijaya University, Palembang.

Shabrina, A. N., Abduh, S. B. M., Hintono, A., \& Pratama, Y. (2017). Physical characteritics of edible film made of arrowroot tuber starch and palm oil. Journal of Food Technology Application, 6(3), 138-142. http://dx.doi.org/10.17728/jatp.239.

Siregar, H. A., Rahmadi, H. Y., Wening, S., \& Suprianto, E. (2018). Fatty acid and carotene composition in Elaeis oleifera, interspecific hybrid, and the first pseudo-backross in North Sumatra, Indonesia. Journal of Oil Palm Research, 26(2), 91-101. http://dx.doi.org/10.22302/ iopri.jur.jpks.v26i2.44.

Thakur, R., Pristijono, P., Golding, J. B., Stathopoulos, C. E., Scarlett, C. J., Bowyer, M., Singh, S. P., \& Vuong, Q. (2017). Amylose-lipid complex as a measure of variations in physical, mechanical and barrier attributes of rice starch- 1 -carrageenan biodegradable edible film. Food Packaging and Shelf Life, 14(2), 108-115. http://dx.doi. org/10.1016/j.fpsl.2017.10.002.

Zheng, K., Li, W., Fu, B., Fu, M., Ren, Q., Yang, F., \& Qin, C. (2018). Physical, antibacterial and antioxidant properties of chitosan films containing hardleaf oatchestnut starch and Litsea cubeba oil. International Journal of Biological Macromolecules, 118(1), 707-715. http://dx.doi.org/10.1016/j.ijbiomac.2018.06.126. PMid:29959016. 